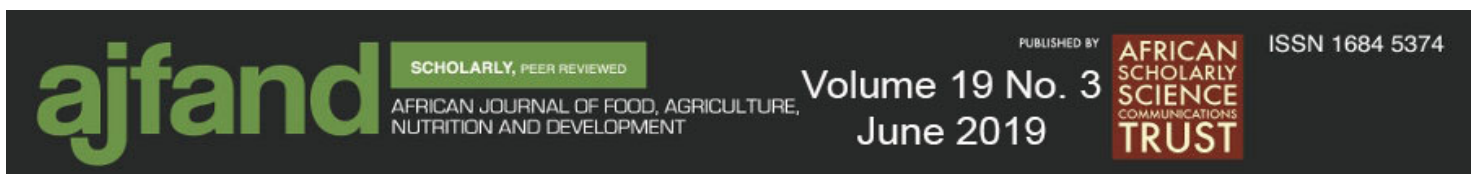

Afr. J. Food Agric. Nutr. Dev. 2019; 19(3): 14708-14725

DOI: 10.18697/ajfand.86.17665

\title{
EFFECT OF COOKING METHODS ON TIME AND NUTRIENT RETENTION OF PIGEON PEA (CAJANUS CAJAN)
}

Adepoju OT ${ }^{1 *}$, Dudulewa BI $^{1}$ and AY Bamigboye ${ }^{2}$

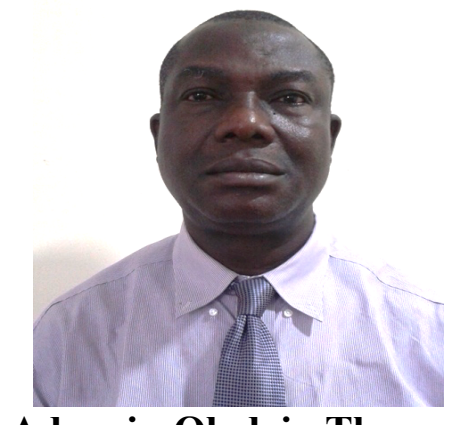

Adepoju Oladejo Thomas

* Corresponding author e-mail address: tholadejo@yahoo.com

${ }^{1}$ Department of Human Nutrition, Faculty of Public Health, College of Medicine, University of Ibadan, Ibadan, Oyo state, Nigeria

${ }^{2}$ Department of Science Laboratory Technology, Faculty of Science, The Polytechnic, Ibadan, Ibadan, Oyo state, Nigeria 


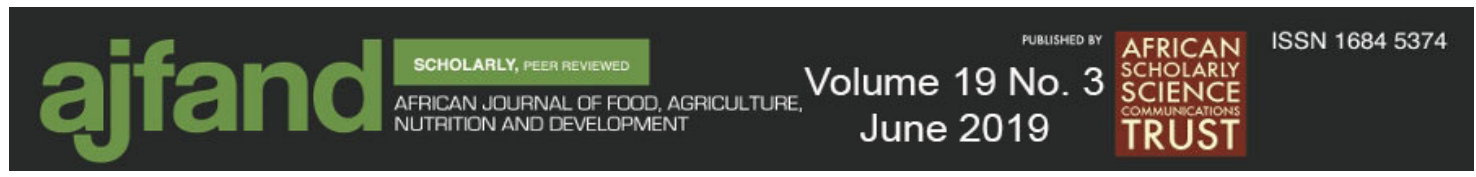

\section{ABSTRACT}

Protein malnutrition is widespread among the rural poor in developing countries and legumes serve as a major source of dietary protein where animal protein is very expensive. Pigeon pea is an important legume with high amount of protein, but its consumption is limited due to its hardness and time-consuming process of cooking. This study was carried out to determine effect of cooking methods on time and nutrient retention of pigeon pea as a means of promoting dietary diversity. Pigeon pea seeds were purchased from Oja Oba market in Ado-Ekiti, Ekiti State, Nigeria, cleaned, sorted, and divided into five portions. One portion was labelled as raw sample. The second portion was washed and cooked with distilled water on an electric cooker at $300^{\circ} \mathrm{C}$ for 2 hours and labelled as Sample 2. The third portion was washed and cooked at $300^{\circ} \mathrm{C}$ for two hours, with decanting and replenishing the water, and labelled as sample 3 . The fourth portion was washed and pressure-cooked with distilled water at $300^{\circ} \mathrm{C}$ for 1 hour and labelled as Sample 4; while the fifth portion was pressure-cooked at $300^{\circ} \mathrm{C}$ for 45 minutes, decanting and replenishing the water, cooked for 15 minutes, then labelled as sample 5. The five samples were analysed in triplicates for proximate, minerals and selected vitamins composition using standard methods of AOAC. Raw pigeon pea contained $11.9 \mathrm{~g}$ moisture, $22.1 \mathrm{~g}$ crude protein, $3.4 \mathrm{~g}$ fat, $3.4 \mathrm{~g}$ ash, $59.0 \mathrm{~g}$ carbohydrates, $47.76 \mathrm{mg}$ sodium, $1025.63 \mathrm{mg}$ potassium, $100.25 \mathrm{mg}$ calcium, $377.87 \mathrm{mg}$ phosphorus, $13.01 \mathrm{mg}$ iron, $11.95 \mathrm{mg}$ zinc, and yielded $315.8 \mathrm{kcal}$ energy $/ 100 \mathrm{~g}$ sample. Boiling, and decanting the boiling water, and pressure cooking led to significant reduction in all macronutrients $(p<0.05)$, the reduction being most pronounced in samples with cooking water decanted. Pressure-cooked samples retained more macronutrients with highest retention recorded in pressure-cooked sample without decanting the water $(p<0.05)$. Boiling without decanting the water had highest retention of minerals, followed by pressure-cooked sample without decanting the water, while boiled sample with decanted water retained least minerals. Pressure cooking the pigeon pea significantly reduced cooking time $(\mathrm{p}<0.05)$, thereby reducing cost of electricity. Pigeon pea is a good source of protein, energy, potassium, calcium, phosphorus, iron and zinc, and can contribute significantly to meeting nutrient needs of consumers; hence, its consumption should be encouraged as a means of dietary diversity among the populace where it is available.

Key words: Protein malnutrition, Pigeon pea, Cooking methods, Nutrient retention, Micronutrient potential 


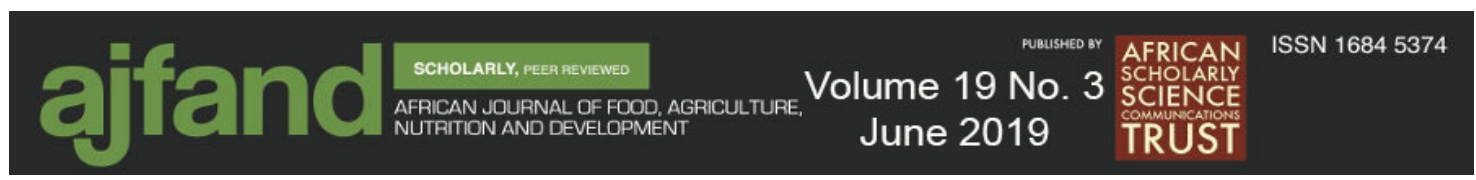

\section{INTRODUCTION}

Protein malnutrition is widespread among the poor in developing countries [1] due to lack of sufficient animal proteins, hence the search for alternative sources of protein from lesser-known legumes in lieu of expensive and scarce animal protein [2]. Legumes represent a major source of energy and nutrients, including protein; particularly in vegetarians' diet [3]. The special contribution of food legumes to human diet lies in the quantity and quality of their protein content.

Among many species of legumes in the plant kingdom, only very few are consumed as food. African yam bean (Sphenostylis stenocarpa Hochst ex A Rich), Lima bean (Phaseolus lunatus), Bambara groundnut (Vigna subterranean), Sword bean (Canavalia gladiata), Jack bean (Canavalia ensiformis), Pigeon pea (Cajanus cajan), and Lablab (Lablab purpureus) are under-utilized legumes that possess high crude protein content between 22 and $37 \%([4,5]$. The low consumption or underutilization of some of these legumes are likely due to hard-to-cook characteristic of the legumes, lack of information regarding their nutritive values, presence of anti-nutrients, taboos and cultural beliefs, and low production [6].

Pigeon pea (Cajanus cajan) is an important food legume that its cultivation has been reported in more than seven countries including Nigeria [7, 8], and is a useful fallow and fodder plant with edible seeds doing best on medium good soils [9]. It is still underutilized as food in Nigeria due to its tough texture, long cooking duration and lack of education on its nutritional potentials [8, 10, 11]. Women cook it using firewood overnight for about 8 - 12 hours. This consequently leads to high loss of nutrients [12]. The seed, apart from being hard to cook is hard to dehull, thus the drudgery process of dehulling the seed is also limiting its utilization into other form of products [13].

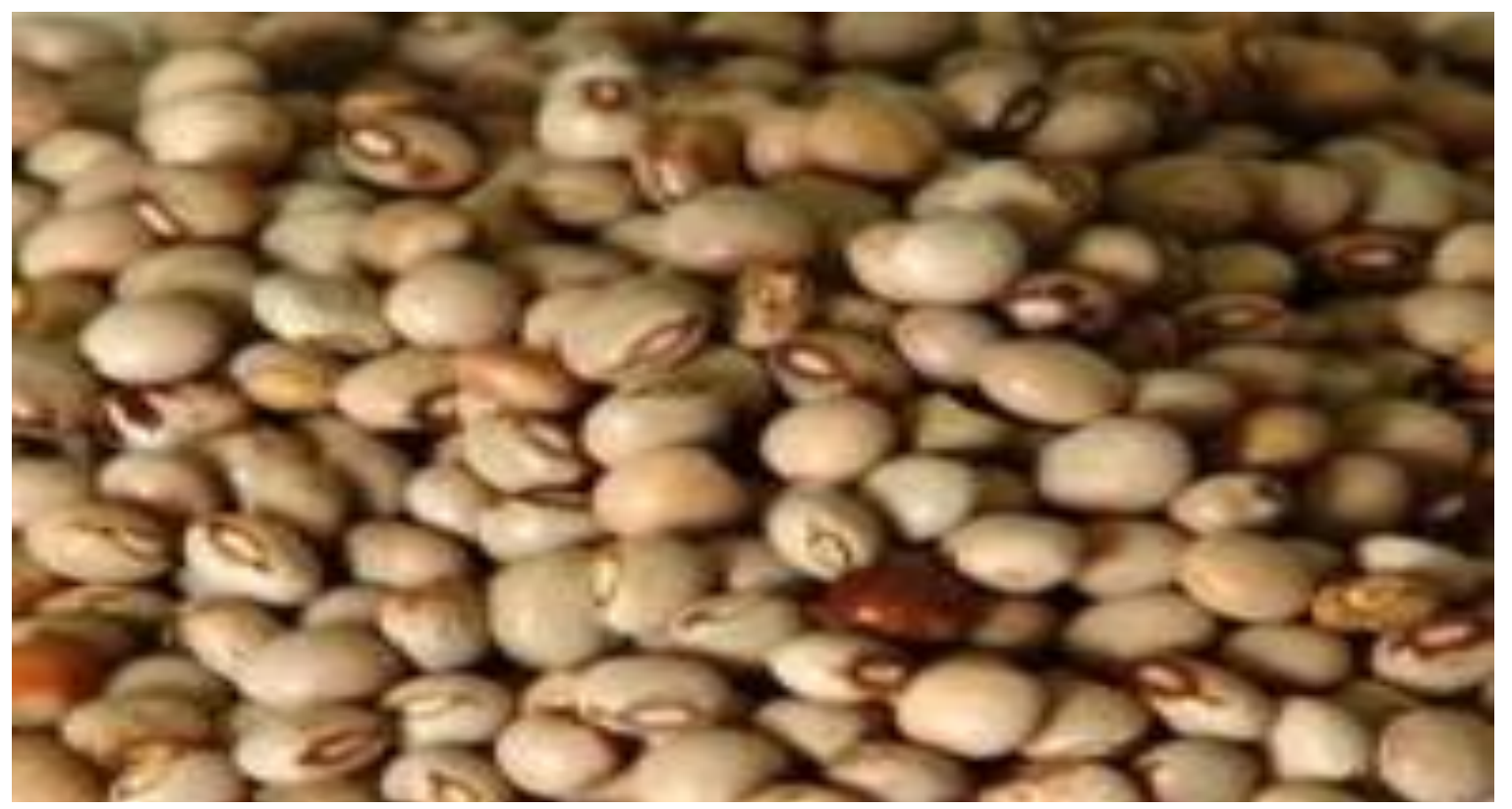

Figure 1: Pigeon Pea Seeds 


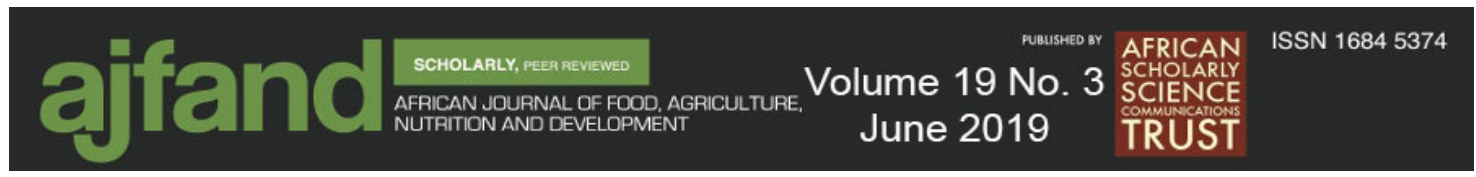

In spite of the fact that chemical composition of pigeon pea has been investigated, little or no information exists in the literature on the effect of cooking methods on its nutrient retention. Adepoju et al. [14] reported reduction in micronutrient content of products from cassava due to processing methods. This study was therefore carried out to determine the effect of cooking methods on nutrient retention and micronutrient potential of pigeon pea.

\section{MATERIALS AND METHODS}

\section{Sample Collection and Preparation}

Pigeon pea seeds were purchased from two stalls at Oja Oba market in Ado-Ekiti, Ekiti State, Nigeria and thoroughly mixed to obtain composite sample. Oja Oba market is a major market where farm produce from different parts of the state are brought for sale, hence the samples bought were believed to be representative of pigeon pea seeds from the State and its environ. The seeds were sorted manually to remove the bad ones, stones, damaged and immature seed, and divided into five portions of $150 \mathrm{~g}$ each. The first portion was ground in a blender and labelled as raw sample (Sample 1) and part of it was used in determining the moisture content, while the rest was oven dried at $60^{\circ} \mathrm{C}$ for 18 hours and then stored in a plastic container at room temperature until when needed for analysis.

One hundred and fifty grammes $(150 \mathrm{~g})$ of each of the remaining four portions was washed with distilled water. The first washed portion was cooked in $750 \mathrm{ml}$ of distilled water on an electric cooker (Stuart SB160) set at $300^{\circ} \mathrm{C}$ for 2 hours to give undecanted sample which was labelled as Sample 2. Another $150 \mathrm{~g}$ of the washed portion was cooked using $500 \mathrm{ml}$ of distilled water on an electric cooker at $300^{\circ} \mathrm{C}$ for 2 hours, with the cooking water decanted at the end of 90 minutes before the seed got softened, and another $250 \mathrm{ml}$ of distilled water added to complete the cooking. This was labelled as Sample 3.

Another $150 \mathrm{~g}$ of the washed portion was pressure-cooked using $750 \mathrm{ml}$ of distilled water at $300^{\circ} \mathrm{C}$ for 1 hour and labelled as Sample 4. The last $150 \mathrm{~g}$ washed portion was also pressure-cooked at $300^{\circ} \mathrm{C}$ for 45 minutes using $500 \mathrm{ml}$ distilled water, decanted, and then $250 \mathrm{ml}$ of distilled water added and cooked for 15 minutes and labelled as Sample 5. Four samples (samples $2-5$ ) were cooked within the stated times till they became tender [15], mashed and oven dried at $60^{\circ} \mathrm{C}$ overnight (18 hours) after determining their moisture content. The oven-dried samples were ground using a warring blender and stored in plastic containers at room temperature for chemical analysis. 


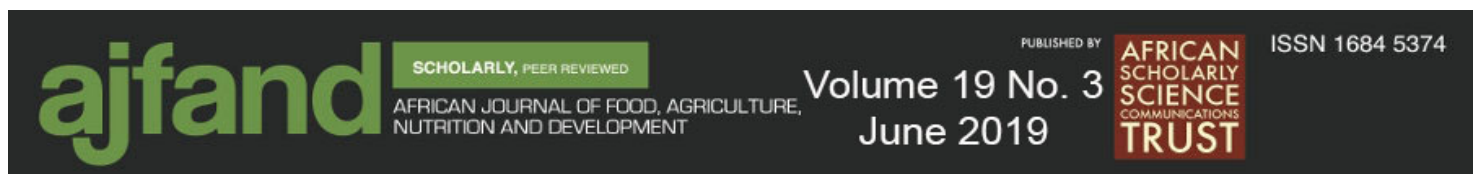

Pigeon Pea Seeds
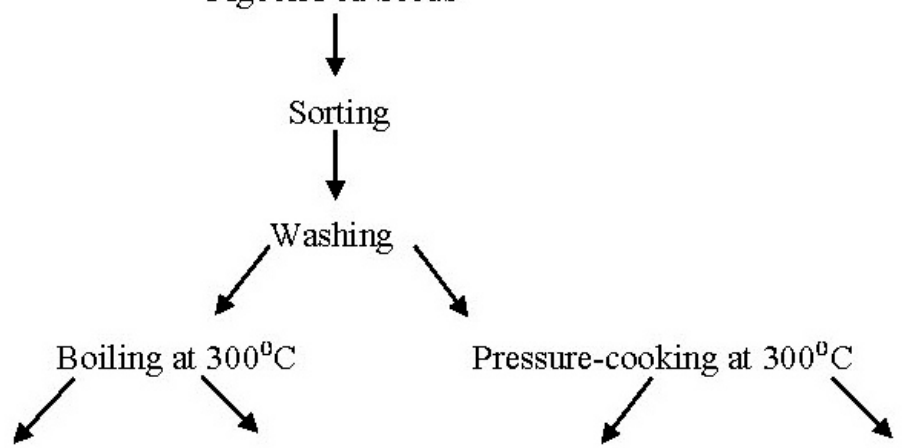

Boiled Pigeon pea

Decanting the water

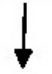

Addition of water

$\downarrow$

Boiled \& Decanted pigeon pea
Pressure-cooked seed

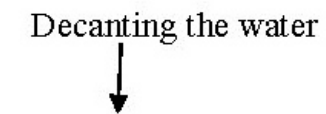

Addition of water

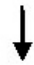

Pressure-cooked \& Decanted pigeon pea

Figure 2: Flow chart for preparation of the pigeon pea product samples

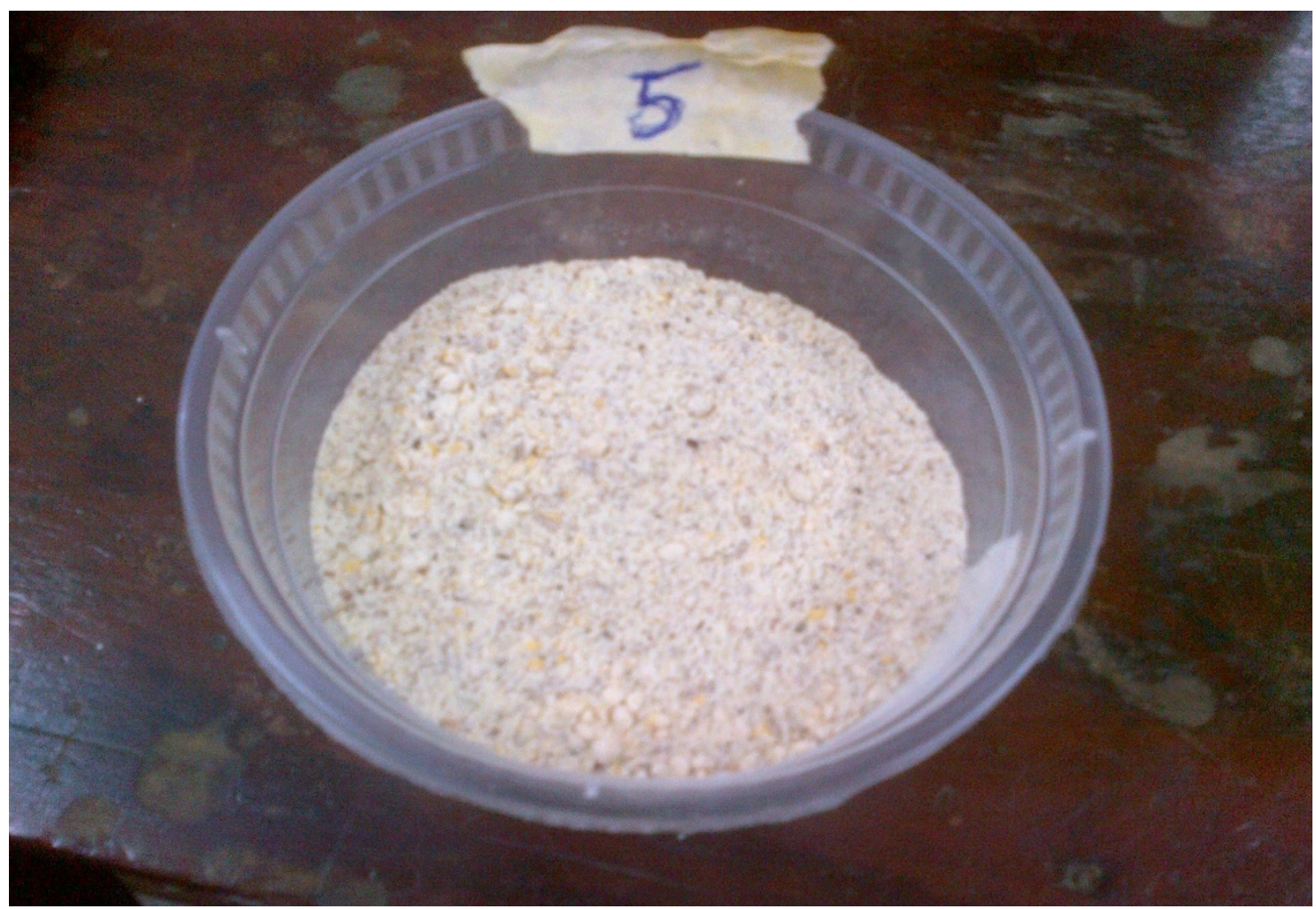

Figure 3: Raw Pigeon pea (Sample 1) 


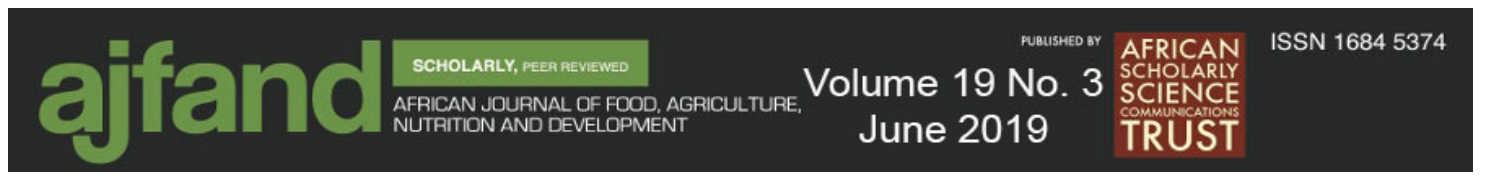

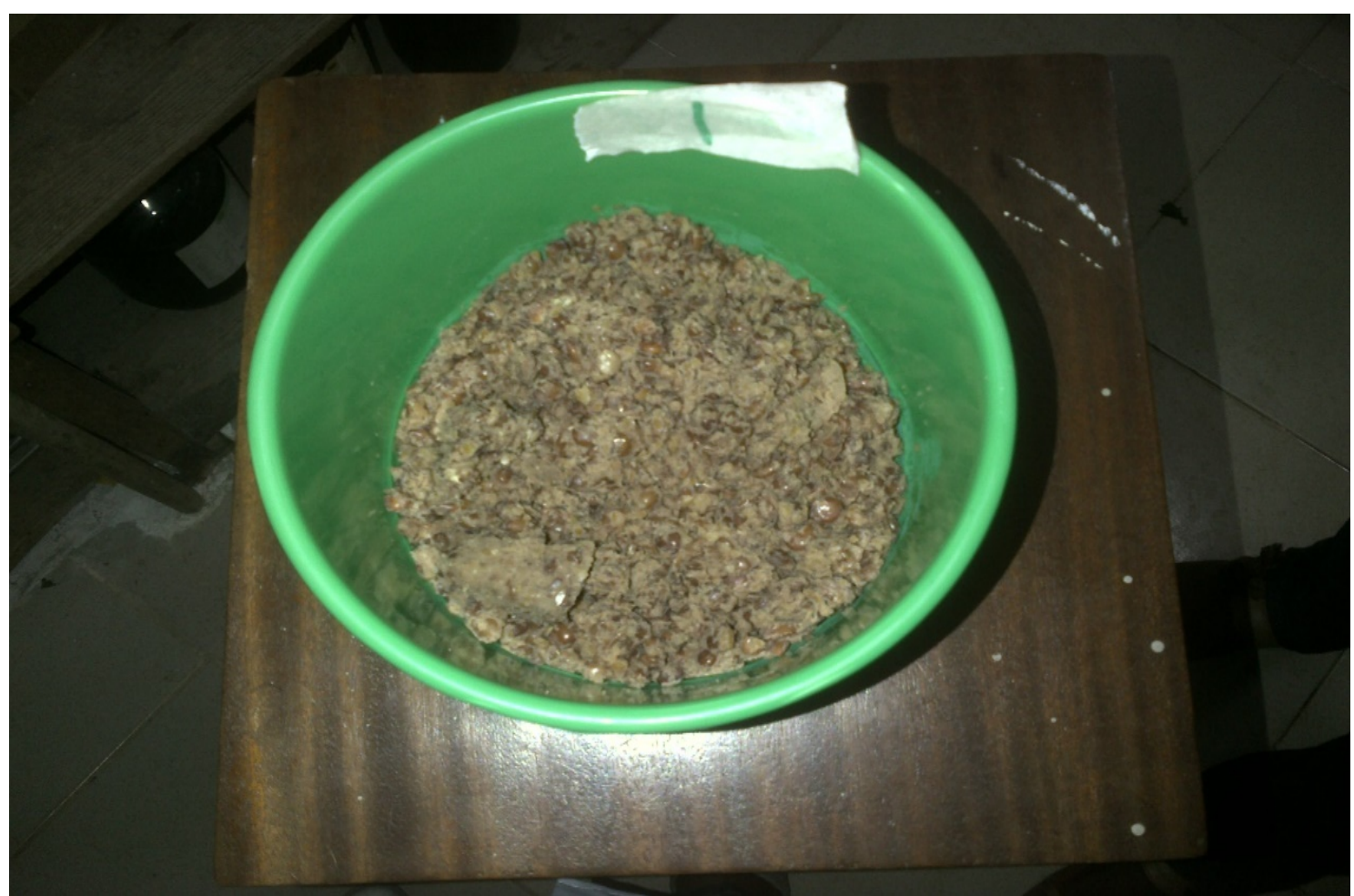

Figure 4: Cooked undecanted Pigeon pea (Sample 2)

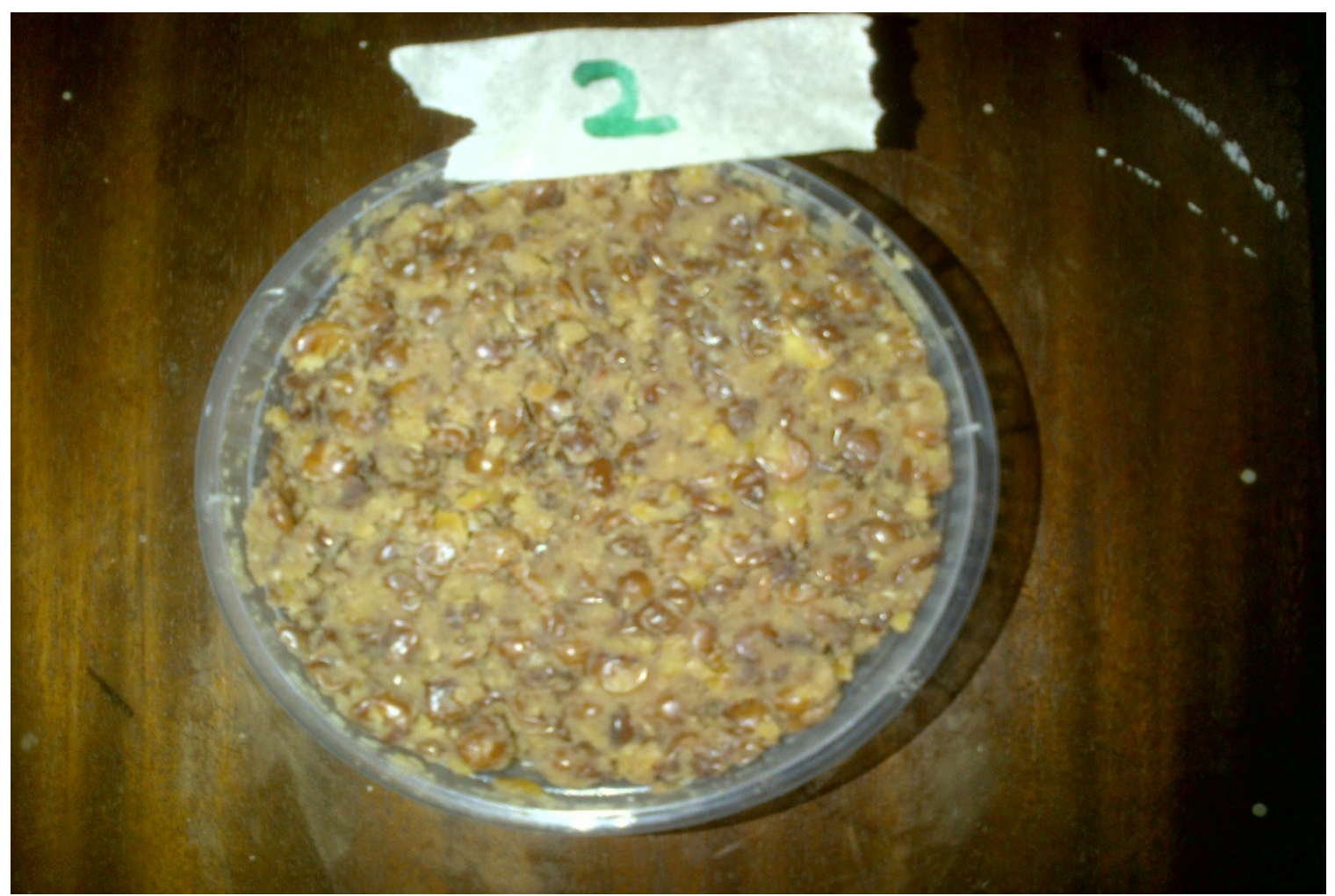

Figure 5: Cooked and decanted Pigeon pea (Sample 3)

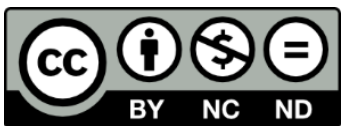




ajfand

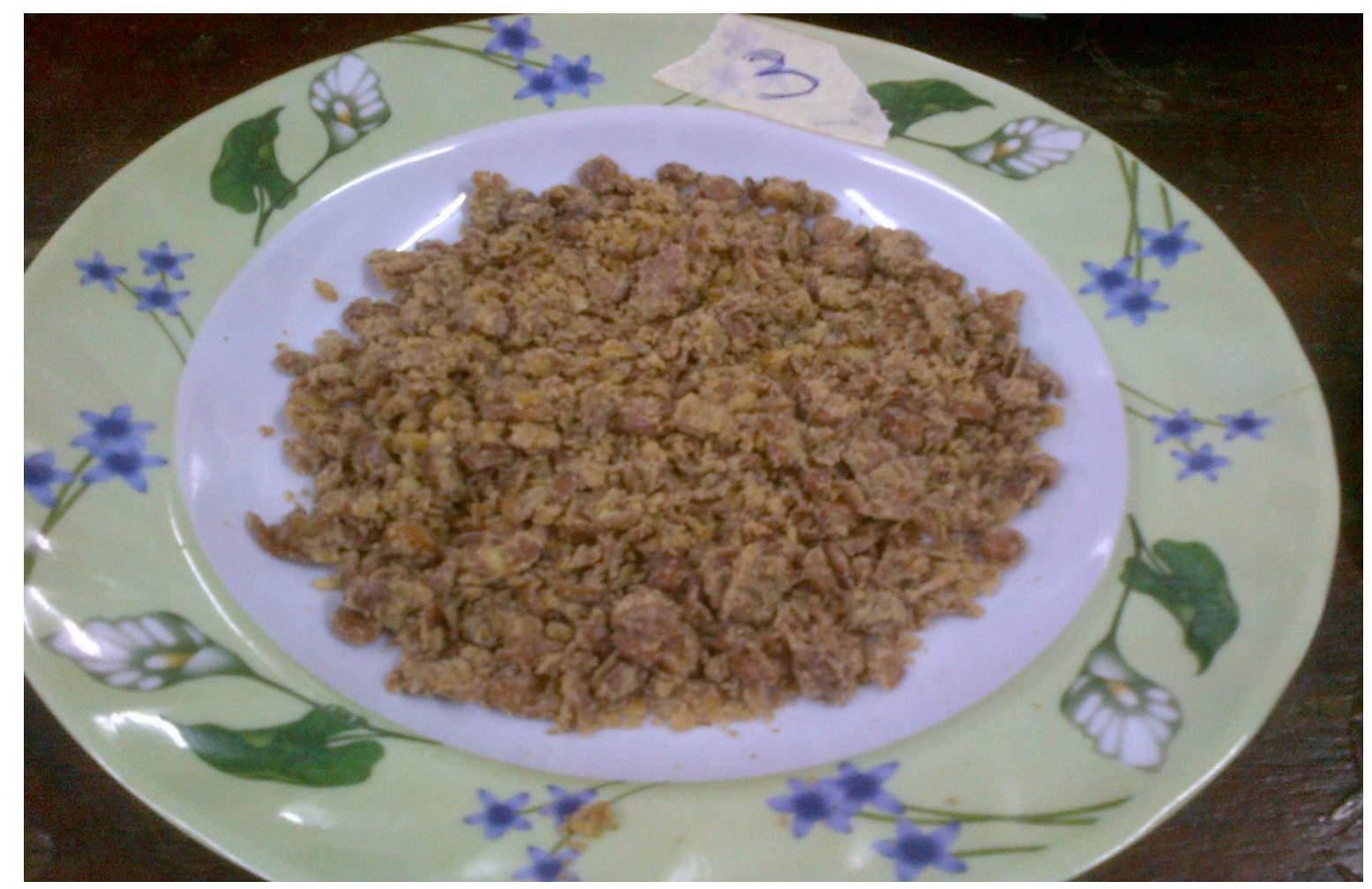

Figure 6: Pressure-cooked undecanted Pigeon pea (Sample 4)

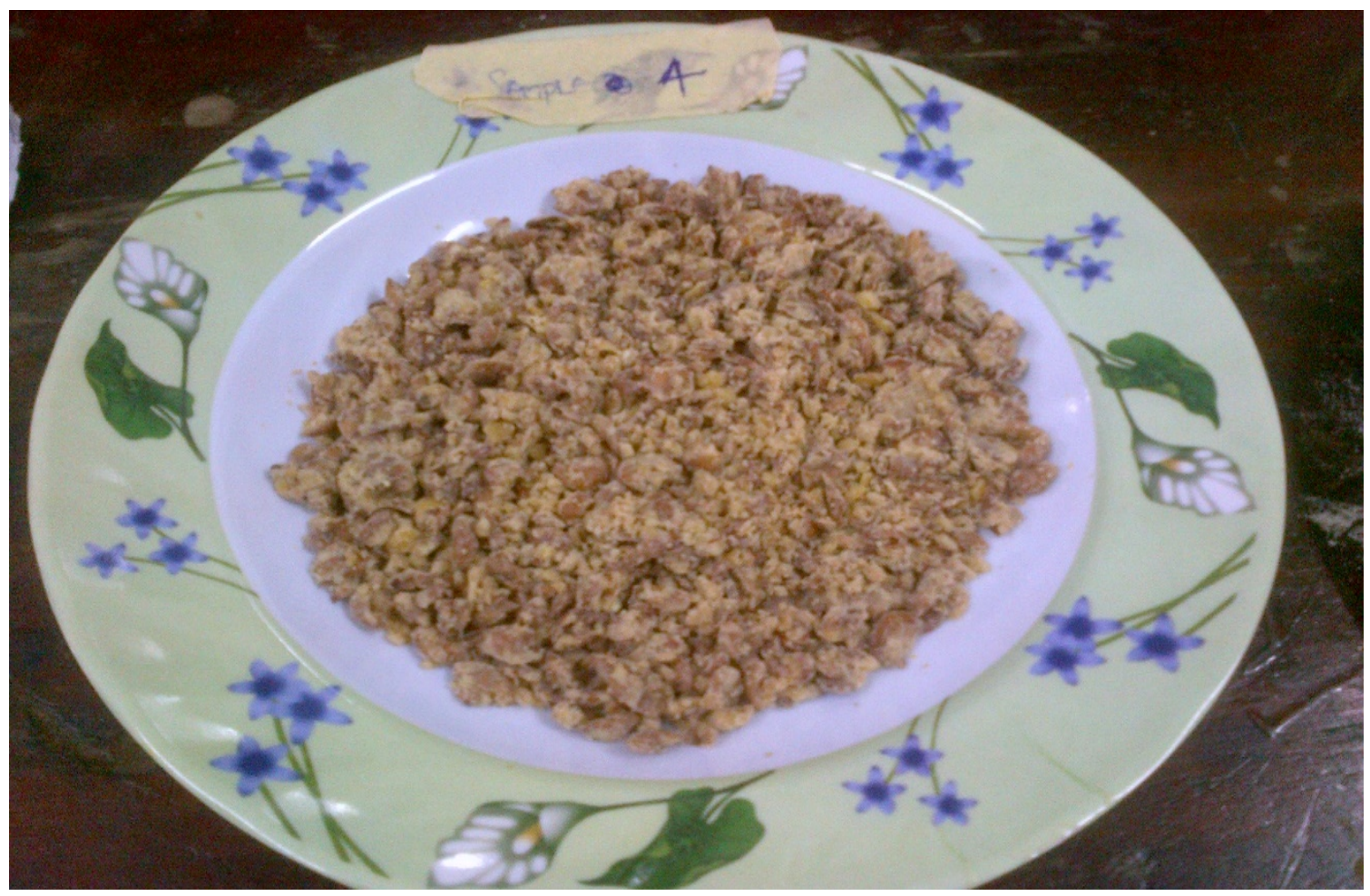

Figure 7: Pressure-cooked and decanted Pigeon pea (Sample 5) 


\section{Chemical Analyses}

\section{Proximate Composition}

Moisture content of the samples was determined by air oven at $105^{\circ} \mathrm{C}$ (Plus 11 Sanyo Gallenkamp PLC UK) for 4 hours. The crude protein of the samples was determined using micro-Kjeldahl method [16] and amount of crude protein calculated using the conversion factor of 6.25. Crude lipid was determined by weighing $5 \mathrm{~g}$ of dried sample into fat free extraction thimble and plugging lightly with cotton wool. The thimble was placed in the Soxhlet extractor fitted up with reflux condenser [16]. The dried sample was extracted with petroleum ether and the crude lipid estimated as $\mathrm{g} / 100 \mathrm{~g}$ dry weight of sample, and then converted to $\mathrm{g} / 100 \mathrm{~g}$ fresh sample weight. The ash content was determined by weighing $5 \mathrm{~g}$ of sample and heated in a muffle furnace (Gallenkamp, size 3) at $550^{\circ} \mathrm{C}$ for 4 hours [16], and ash calculated as $\mathrm{g} / 100 \mathrm{~g}$ original sample. Total carbohydrate content was obtained by difference. Gross energy content of the samples was determined using ballistic bomb calorimeter (Cal 2k - Eco, TUV Rheinland Quality Services (Pty) Ltd, South Africa).

\section{Mineral Analysis}

Potassium and sodium content of the samples were determined by digesting the ash of the samples with Perchloric acid and nitric acid, and then taking the readings on Jenway digital flame photometer/spectronic20 [16]. Phosphorus was determined by vanadomolybdate colorimetric method [16]. Calcium, magnesium, iron zinc, manganese and copper were determined spectrophotometrically by using Buck 200 atomic absorption spectrophotometer (Buck Scientific, Norwalk) and absorption of the sample mineral compared with absorption of standards of these minerals [16].

\section{$\beta$-Carotene Determination}

The $\beta$-carotene content of the samples was determined through ultraviolet absorption measurement at $328 \mathrm{~nm}$ after extraction with chloroform. Calibration curve of $\beta$-carotene standard solutions was made and the sample $\beta$-carotene concentration estimated as microgram $(\mu \mathrm{g})$ of $\beta$-carotene $/ 100 \mathrm{~g}$ sample [16].

\section{Thiamine (Vitamin $B_{1}$ ) Determination}

Thiamine content of the samples (raw and cooked) was determined by weighing $1 \mathrm{~g}$ of each sample into $100 \mathrm{ml}$ volumetric flask and adding $50 \mathrm{ml}$ of $0.1 \mathrm{M} \mathrm{H}_{2} \mathrm{SO}_{4}$ and boiled in a boiling water bath with frequent shaking for 30 minutes. Five millilitre of $2.5 \mathrm{M}$ sodium acetate solution was added and flask set in cold water to cool contents below $50^{\circ} \mathrm{C}$. The flask was stoppered and kept at $45-50^{\circ} \mathrm{C}$ for 2 hours and thereafter made up to $100 \mathrm{ml}$ mark. The mixture was filtered through a No. 42 Whatman filter paper, discarding the first $10 \mathrm{ml}$. Ten $(10 \mathrm{ml})$ was pipetted from remaining filtrate into a $50 \mathrm{ml}$ volumetric flask and $5 \mathrm{ml}$ of acid potassium chloride solution was added with thorough shaking. Standard thiamine solutions were prepared and treated same way. The absorbance of the sample as well as that of the standards was read on a fluorescent UV Spectrophotometer (Cecil A20 Model) at a wavelength of $285 \mathrm{~nm}$. 


\section{Riboflavin (Vitamin $B_{2}$ ) Determination}

One gramme (1g) of each sample (raw and cooked) was weighed into a $250 \mathrm{ml}$ volumetric flask, $5 \mathrm{ml}$ of $1 \mathrm{M} \mathrm{HCl}$ was added, followed by the addition of $5 \mathrm{ml}$ of dichloroethene. The mixture was shaken and $90 \mathrm{ml}$ of de-ionized water was added. The whole mixture was thoroughly shaken and was heated on a steam bath for 30 minutes to extract all the riboflavin. The mixture was then cooled and made up to volume with de-ionized water. It was then filtered, discarding the first $20 \mathrm{ml}$ of the aliquot, and $2 \mathrm{ml}$ of the filterate obtained was pipetted into another $250 \mathrm{ml}$ volumetric flask and made up to mark with deionized water. Sample absorption was read on the fluorescent spectrophotometer at a wavelength of $460 \mathrm{~nm}$. Standard solutions of riboflavin were prepared and readings taken at $460 \mathrm{~nm}$, and the sample riboflavin obtained through calculation.

\section{Niacin (Vitamin $B_{3}$ ) determination}

$5 \mathrm{~g}$ of sample was extracted with $100 \mathrm{ml}$ of distilled water and $5 \mathrm{ml}$ of this solution was drawn into $100 \mathrm{ml}$ volumetric flask and make up to mark with distilled water. Standard solutions of niacin were prepared and absorbance of sample and standard solutions were measured at a wavelength of $385 \mathrm{~nm}$ on a spectrophotometer and niacin concentration of the sample estimated.

\section{Ascorbic Acid Determination}

Ascorbic acid in the sample was determined by titrating its aqueous extract with solution of 2, 6-dichlorophenol-indophenol dye to a faint pink end point [16].

\section{Apparent Nutrient Retention of Cooked foods}

The \% apparent retention (AR) of nutrients was calculated by the formula of Murphy et al. [17]:

$$
\% \mathrm{AR}=\frac{\text { Nutrient content per } \mathrm{g} \text { of cooked food on dry basis } \mathrm{x}}{\text { Nutrient content per } \mathrm{g} \text { of raw food on dry basis }}
$$

All determinations were carried out in triplicate and data obtained interpreted statistically using Analysis of Variance (ANOVA) and Post Hoc Test at $\mathrm{p}<0.05$.

\section{RESULTS AND DISCUSSION}

\section{Proximate Composition}

The results of proximate composition of raw and cooked pigeon pea are shown in Table 1. The moisture content of the raw sample was low $(11.9 \pm 0.31 \mathrm{~g} / 100 \mathrm{~g})$, while that of cooked samples were very high $(\mathrm{p}<0.05)$, with sample 3 (boiled decanted sample) having the highest value, followed by sample 5 (pressure-cooked decanted sample), and the pressure cooked undecanted sample (Sample 4) had the lowest value. There were significant differences $(\mathrm{p}<0.05)$ between the moisture content of the cooked samples.

The raw sample was high in crude protein content, while highly significant reduction $(p<0.05)$ was recorded in protein content of the cooked samples when compared with the raw one. Pressure-cooked undecanted sample (sample 4) had the highest value of crude protein while the boiled and decanted sample (sample 3) had the lowest. There was also 
a significant difference in protein content of sample 4 and the rest of cooked samples $(p<0.05)$, while there was no significant difference in its value for samples 2 and 5, which were significantly higher than that of sample 3 .

Raw pigeon pea sample was very low crude lipid, and the cooked samples still recorded further significant reduction in value $(\mathrm{p}<0.05)$. The cooked decanted sample had the lowest crude lipid value while the pressure-cooked undecanted sample had the highest value. A significant reduction in lipid content was observed in the cooked samples $(p<0.05)$. The ash content of raw and cooked samples differed significantly $(p<0.05)$. There was no significant difference in ash values for samples 2,3 , and 4 , while sample 5 had the lowest ash content which was significantly lower than the rest $(\mathrm{p}<0.05)$.

The raw sample was high in total carbohydrate content compared to the rest of the nutrients. There was a highly significant reduction in its value in the cooked samples $(p<0.05)$. There were significant differences in carbohydrate content of the cooked samples $(\mathrm{p}<0.05)$, the pressure-cooked undecanted sample (Sample 4) having the highest value while the boiled and decanted sample (Sample 3) had the lowest value. There was no significant difference $((\mathrm{p}>0.05)$ between the boiled and decanted sample (Sample 2$)$ and the pressure-cooked and decanted sample (Sample 5).

The gross energy content of the raw sample was high, while the cooked samples were significantly lower $(\mathrm{p}<0.05)$. The pressure-cooked and decanted sample had the highest value and the boiled undecanted sample having lowest value among the cooked samples. The value obtained for the moisture content of the raw sample was well within the range reported by Amarteifio et al. [18], while Abdel et al. [19] reported a lower value of $8 \%$. The observed variation in the moisture content could be attributed to the degree of dryness and length of storage of the pea, as stored products do lose moisture during storage. The moisture content of the cooked samples was higher than that of raw sample due to absorption of water during cooking which had a dilution effect on all other nutrients [20].

The crude protein value of the raw sample was within the range reported in the literature $[21,22,23]$, higher than the $21.0 \%$ reported by Abdel [19], and lower than the $27.15 \%$ reported by Onu and Okongwu [24]. The disparity observed might be due to varietal differences or geographic variation. The protein content of pigeon pea is slightly higher than that of commonly consumed beans (Vigna unguiculata and Vigna angustifoliata) reported by Bamigboye and Adepoju [25]. Its protein value qualifies it as a good source of plant protein which can contribute to meeting the daily protein dietary requirements of consumers.

Cooking resulted in significant reduction in the protein content of the products of pigeon pea. This finding is in agreement with that reported in the literature [4, 24], that reported a decrease in crude protein content of pigeon pea seeds with boiling. The reduction in crude protein value of pigeon pea could be associated with increase in moisture content of the samples, and leaching of soluble protein part of the seeds into the boiling water. This is supported by the lower protein values recorded for samples 3 and 5, in which the cooking water was decanted and replaced with fresh ones. 
The crude lipid value of the raw sample was similar to the one in the literature [3], but higher than the one reported for Vigna unguiculata and Vigna angustifoliata [25]. The significant reduction in crude lipid content observed in the cooked samples was believed to be due to increase in moisture content of the samples, as well as decantation of the cooking water. The ash content of the raw pigeon pea was in agreement with that of Abdel et al. [19], but lower than the range reported by Amarteifio et al. [18]. The substantial reduction in ash content of boiled samples was believed to be due to increase in the moisture content of the samples, as well as leaching of both micro and macro minerals into the decanted water.

The total carbohydrate content of the raw sample in this study was in agreement with the values reported by Adeparusi [26], but slightly lower than 61.40\% reported by Abdel et al. [19] and Amaefule and Obioha [11]. However, the cooked samples had a significantly lower content of total carbohydrates than the raw form. The significant reduction in carbohydrate value in cooked samples was believed to be due to the increase in moisture content of the cooked samples.

The gross energy value obtained for raw pigeon pea in this study is within the range reported by Adebowale and Malik [2], but significantly lower than the value (369.38 $\mathrm{kcal} / 100 \mathrm{~g}$ ) reported by Arawande and Borokini [27]. Various cooking methods increased the gross energy content of pigeon pea.

\section{Mineral Composition}

Pigeon pea was very high in potassium, phosphorus, iron and zinc, high in calcium, manganese and copper, but low in sodium and magnesium (Table 2). There were highly significant reductions in all mineral contents of the cooked pea samples compared to the raw $(p<0.05)$, the reductions being more pronounced in the samples where the cooking water was decanted. The cooked undecanted sample (sample 2) retained more potassium, sodium, phosphorus, iron, zinc manganese and copper, while pressure-cooked undecanted sample (sample 4) retained more magnesium.

The value obtained for sodium content in raw sample (sample 1, Table 2) is in line with the finding of Bamigboye and Adepoju [25], which revealed that pulses are generally low in sodium content. The low sodium content of pigeon pea is an advantage for its suitability for consumption by all. The high potassium content of the pea can be beneficial to patients who take diuretics to control hypertension and those who suffer from excessive excretion of potassium through body fluids. The daily potassium requirement for the adults is $2,000 \mathrm{mg}$ [28], and $100 \mathrm{~g}$ portion of raw pigeon pea can supply half of this daily requirement.

The calcium content of the raw sample was higher than the values recorded for Vigna unguiculata and Vigna angustifoliata [25], which are commonly consumed in Nigeria. The magnesium content of the raw sample was in agreement with the range reported by Meiner et al. [29]. The iron, zinc, copper, and manganese content also were in agreement with that of Nwokolo [30] who reported these minerals in pigeon pea meal. However, 


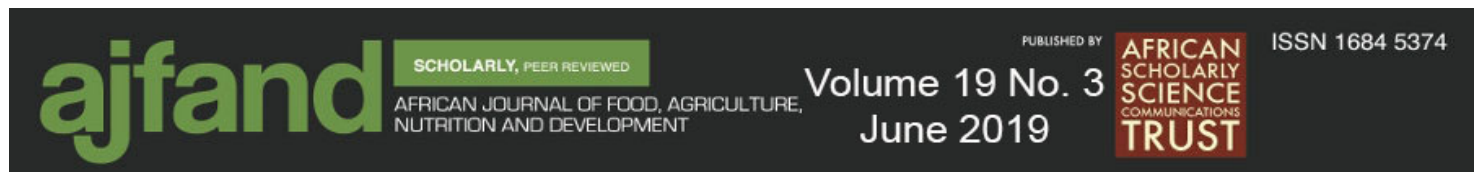

the values of these minerals were higher than that of Vigna unguiculata and Vigna angustifoliata [25].

The different processing methods such as boiling, boiling and decanting, pressurecooking, pressure-cooking and decanting significantly reduced the mineral content of cooked samples (samples $2-5$ ). This observation is in line with the assertion of Meiner et al. [29] who stated that the mineral content in cooked legumes was about one-third to one-half of the values in raw legumes.

\section{Selected Vitamins Composition}

The legume was low in $\beta$-carotene, thiamine, riboflavin, niacin and ascorbic acid (Table 3). Various cooking methods significantly increased the vitamin content of the samples, the decanted samples being higher in value $(\mathrm{p}<0.05)$. Pressure-cooked decanted sample (sample 5) had highest retention value for the cooked products.

The result of the thiamine, riboflavin, and niacin content of the raw sample (Table 3) was in close agreement with the values reported by Faris et al. [31]. However, the beta carotene and the ascorbic acid content of the raw sample in this study were different from the values reported by Faris et al. [31]. The observed variation in values may likely be due to yearly and geographic variation. However, cooking generally enhanced the vitamin content of the cooked samples significantly $(\mathrm{p}<0.05)$, the decanted samples (Samples 3 and 5) being significantly higher than the undecanted samples (samples 2 and 4). Pressure cooked samples were significantly higher in vitamins than the cooked samples. No possible explanation can be given for the trend being observed in the vitamin content of the cooked samples. The higher nutrient value of all the cooked samples above the raw is an indication that application of heat on pigeon pea releases more nutrients from their bound state to make them more readily available.

\section{Nutrient Retention}

Cooked undecanted sample (sample 2) retained more minerals than the rest of the samples (Table 4), cooked decanted sample (sample 3) retained more carbohydrates, ash, $\beta$-carotene and calcium, pressure-cooked undecanted sample (sample 4) retained more riboflavin, while pressure-cooked decanted sample (sample 5) retained more lipid, thiamine and niacin.

There was no specific pattern of nutrient retention among the various cooking methods used (Table 4). However, pressure-cooked undecanted sample (sample 40 retained more macronutrients, signifying a better method of cooking and retaining more nutrients in the cooked pea. All the cooking methods retained more than two-third of all nutrients studied. Boiled sample without discarding the cooking water retained highest amount of minerals, followed by pressure-cooking without decanting the water. This was expected, as decanting will lead to loss of soluble minerals in the decanted water [14]. The result of this study is at variance with the report of Murphy et al. [17] who compared the apparent and true retention of nutrients in different cooked foods, including legumes and found the highest retention for crude fibre and lowest retention for ash. Decanting seems to enhance the values of the water-soluble vitamins in the samples. Possible explanation for this may be due to the removal of masking effect of some components of the pigeon 


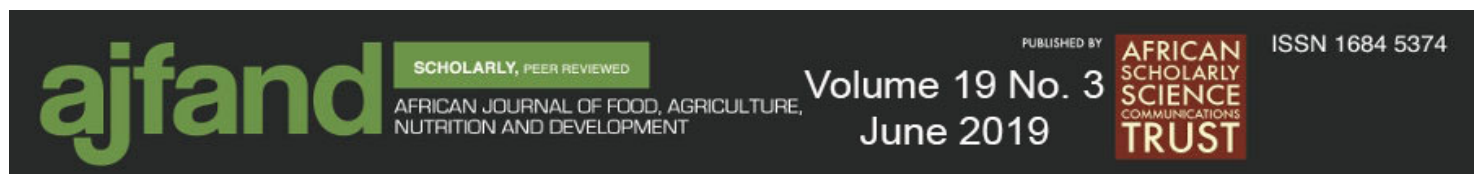

pea which are removed by decanting, thereby allowing fresh water to penetrate and facilitate the release of the vitamins. Beta carotene was retained most in all the samples, while the lowest retention was observed in riboflavin in all the samples.

\section{CONCLUSION}

Pigeon pea is rich in potassium, calcium, phosphorus, iron, zinc, manganese and copper, and could be a good source of these minerals. Boiling, boiling and decanting led to significant nutrient loss in the cooked samples compared to the raw samples. However, cooking without decanting the cooking water retained more nutrients for both boiled and pressure-cooked samples. The use of pressure cooker in cooking pigeon pea can reduce the problem associated with time and energy consumption in its of cooking. Consumption of this variety of pulses should be encouraged to promote dietary diversity and ensure adequate dietary intake, as well as contribute substantially to good health and well-being of consumers in the areas where this type of pulse exists. 


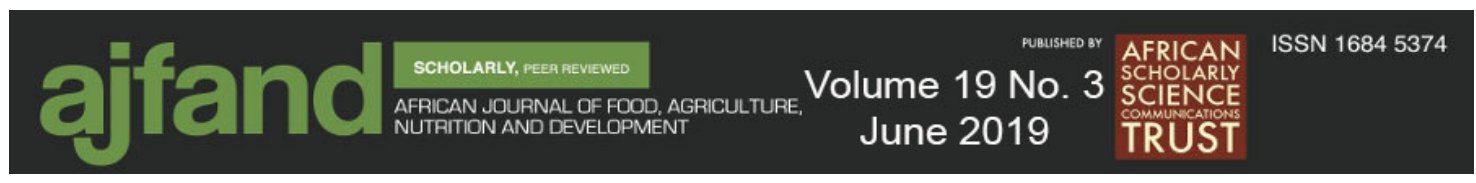

Table 1: Proximate composition of raw and cooked pigeon pea $(\mathrm{g} / \mathbf{1 0 0 g})$

\begin{tabular}{|l|l|l|l|l|l|}
\hline Parameter & Sample 1 & Sample 2 & Sample 3 & Sample 4 & Sample 5 \\
\hline Moisture & $11.9 \pm 0.311^{\mathrm{a}}$ & $61.9 \pm 0.15^{\mathrm{b}}$ & $65.7 \pm 0.19^{\mathrm{c}}$ & $60.0 \pm 0.26^{\mathrm{d}}$ & $63.6 \pm 0.26^{\mathrm{e}}$ \\
\hline Crude Protein & $23.1 \pm 0.14^{\mathrm{a}}$ & $9.1 \pm 0.06^{\mathrm{b}}$ & $7.9 \pm 0.08^{\mathrm{c}}$ & $10.1 \pm 0.05^{\mathrm{d}}$ & $8.8 \pm 0.11^{\mathrm{b}}$ \\
\hline Crude Lipid & $3.4 \pm 0.02^{\mathrm{a}}$ & $1.4 \pm 0.01^{\mathrm{b}}$ & $1.3 \pm 0.02^{\mathrm{c}}$ & $1.6 \pm 0.02^{\mathrm{d}}$ & $1.5 \pm 0.02^{\mathrm{e}}$ \\
\hline Ash & $1.7 \pm 0.02^{\mathrm{a}}$ & $0.7 \pm 0.02^{\mathrm{b}}$ & $0.7 \pm 0.01^{\mathrm{b}}$ & $0.7 \pm 0.02^{\mathrm{b}}$ & $0.6 \pm 0.01^{\mathrm{c}}$ \\
\hline$*$ Total carbohydrates & $59.9 \pm 0.16^{\mathrm{a}}$ & $27.0 \pm 0.12^{\mathrm{b}}$ & $24.4 \pm 0.10^{\mathrm{c}}$ & $27.6 \pm 0.19^{\mathrm{d}}$ & $25.1 \pm 0.14^{\mathrm{c}}$ \\
\hline Gross Energy $(\mathrm{kcal} /)$ & $315.0 \pm 0.60^{\mathrm{a}}$ & $318.5 \pm 0.31^{\mathrm{b}}$ & $320.3 \pm 0.16^{\mathrm{b}}$ & $321.1 \pm 0.25^{\mathrm{b}}$ & $326.4 \pm 0.30^{\mathrm{c}}$ \\
\hline
\end{tabular}

Values with the same superscript on the same row are not significantly different while values with different superscripts are significantly different

*Total carbohydrates $=$ Available carbohydrates + fibre

Sample $1=$ Raw pigeon pea, Sample $2=$ Boiled undecanted pigeon pea, Sample $3=$ Boiled and decanted pigeon pea, Sample $4=$ Pressure cooked undecanted pigeon pea, and Sample $5=$ Pressure cooked and decanted pigeon pea.

Table 2: Mineral composition of raw and cooked pigeon pea (mg/100g)

\begin{tabular}{|l|l|l|l|l|l|}
\hline Parameter & Sample 1 & Sample 2 & Sample 3 & Sample 4 & Sample 5 \\
\hline Sodium & $47.76 \pm 0.37^{\mathrm{a}}$ & $18.52 \pm 0.34^{\mathrm{b}}$ & $14.52 \pm 0.24^{\mathrm{c}}$ & $15.93 \pm 0.21^{\mathrm{d}}$ & $11.67 \pm 0.27^{\mathrm{c}}$ \\
\hline Potassium & $1025.63 \pm 3.18^{\mathrm{a}}$ & $449.12 \pm 3.83^{\mathrm{b}}$ & $381.98 \pm 1.39^{\mathrm{c}}$ & $433.81 \pm 3.97^{\mathrm{d}}$ & $393.90 \pm 3.41^{\mathrm{c}}$ \\
\hline Calcium & $100.25 \pm 0.34^{\mathrm{a}}$ & $46.35 \pm 0.33^{\mathrm{b}}$ & $43.41 \pm 0.26^{\mathrm{c}}$ & $46.29 \pm 0.50^{\mathrm{b}}$ & $44.16 \pm 0.37^{\mathrm{d}}$ \\
\hline Magnesium & $84.31 \pm 0.32^{\mathrm{a}}$ & $39.66 \pm 0.67^{\mathrm{b}}$ & $35.05 \pm 0.21^{\mathrm{c}}$ & $40.62 \pm 0.38^{\mathrm{b}}$ & $37.36 \pm 0.22^{\mathrm{d}}$ \\
\hline Phosphorus & $377.87 \pm 3.39^{\mathrm{a}}$ & $161.77 \pm 0.59^{\mathrm{b}}$ & $143.06 \pm 1.79^{\mathrm{c}}$ & $151.67 \pm 2.51^{\mathrm{d}}$ & $132.86 \pm 2.34^{\mathrm{c}}$ \\
\hline Iron & $13.01 \pm 0.20^{\mathrm{a}}$ & $5.37 \pm 0.12^{\mathrm{b}}$ & $3.91 \pm 0.12^{\mathrm{c}}$ & $4.21 \pm 0.15^{\mathrm{d}}$ & $3.27 \pm 0.65^{\mathrm{c}}$ \\
\hline Zinc & $11.95 \pm 0.35^{\mathrm{a}}$ & $4.99 \pm 0.08^{\mathrm{b}}$ & $3.62 \pm 0.04^{\mathrm{c}}$ & $3.89 \pm 0.09^{\mathrm{d}}$ & $3.37 \pm 0.09^{\mathrm{c}}$ \\
\hline Manganese & $7.01 \pm 0.18^{\mathrm{a}}$ & $2.84 \pm 0.08^{\mathrm{b}}$ & $2.34 \pm 0.07^{\mathrm{c}}$ & $2.45 \pm .04^{\mathrm{d}}$ & $1.96 \pm 0.12^{\mathrm{c}}$ \\
\hline Copper & $3.31 \pm 0.13^{\mathrm{a}}$ & $1.23 \pm 0.16^{\mathrm{b}}$ & $0.85 \pm 0.07^{\mathrm{c}}$ & $0.84 \pm 0.07^{\mathrm{c}}$ & $0.66 \pm 0.08^{\mathrm{d}}$ \\
\hline
\end{tabular}

Values with the same superscript on the same row are not significantly different while values with different superscripts are significantly different 


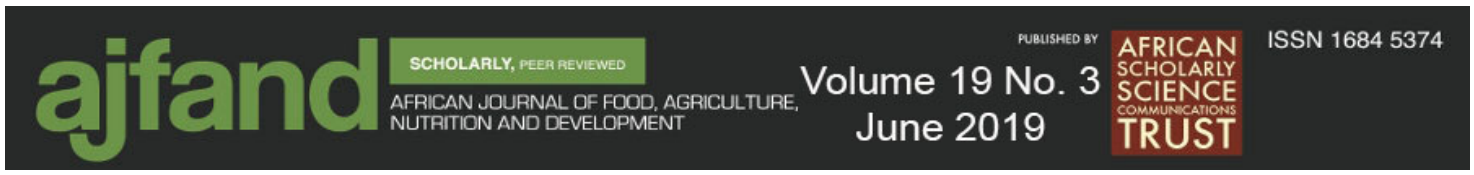

Table 3: Vitamin composition of raw and processed pigeon pea $(\mathrm{mg} / \mathbf{1 0 0 g})$

\begin{tabular}{|l|l|l|l|l|l|}
\hline Parameter & Sample 1 & Sample 2 & Sample 3 & Sample 4 & Sample 5 \\
\hline$\beta$-carotene $(\mu \mathrm{g} /)$ & $23.31 \pm 0.04^{\mathrm{a}}$ & $28.92 \pm 0.05^{\mathrm{b}}$ & $27.66 \pm 2.85^{\mathrm{c}}$ & $26.91 \pm 0.04^{\mathrm{d}}$ & $31.25 \pm 0.03^{\mathrm{c}}$ \\
\hline Thiamine & $0.25 \pm 0.02^{\mathrm{a}}$ & $0.32 \pm 0.01^{\mathrm{b}}$ & $0.36 \pm 0.02^{\mathrm{c}}$ & $0.4 \pm 0.03^{\mathrm{d}}$ & $0.54 \pm 0.02^{\mathrm{c}}$ \\
\hline Riboflavin & $0.09 \pm 0.02^{\mathrm{a}}$ & $0.07 \pm 0.03^{\mathrm{b}}$ & $0.16 \pm 0.03^{\mathrm{c}}$ & $0.14 \pm 0.03^{\mathrm{d}}$ & $0.24 \pm 0.02^{\mathrm{c}}$ \\
\hline Niacin & $2.30 \pm 0.20^{\mathrm{a}}$ & $2.77 \pm 0.31^{\mathrm{b}}$ & $3.13 \pm 0.25^{\mathrm{c}}$ & $3.33 \pm 0.25^{\mathrm{d}}$ & $3.87 \pm 0.25^{\mathrm{c}}$ \\
\hline Ascorbic acid & $1.71 \pm 0.03^{\mathrm{a}}$ & $1.89 \pm 0.03^{\mathrm{b}}$ & $2.06 \pm 0.02^{\mathrm{c}}$ & $2.13 \pm 0.02^{\mathrm{d}}$ & $2.63 \pm 0.03^{\mathrm{c}}$ \\
\hline
\end{tabular}

Values with the same superscript on the same row are not significantly different while values with different superscripts are significantly different

Table 4: Percent nutrient retention by different cooking methods

\begin{tabular}{|l|l|l|l|l|}
\hline Parameter & Sample 2 & Sample 3 & Sample 4 & Sample 5 \\
\hline Crude protein & 81.40 & 77.32 & 89.57 & 87.75 \\
\hline Crude lipid & 95.39 & 93.77 & 103.25 & 105.15 \\
\hline Carbohydrate & 102.52 & 103.79 & 100.86 & 100.23 \\
\hline Ash & 107.67 & 111.25 & 98.21 & 96.93 \\
\hline$\beta$-carotene & 74.59 & 92.50 & 88.51 & 86.11 \\
\hline Thiamine & 46.30 & 59.26 & 66.67 & 74.07 \\
\hline Riboflavin & 37.50 & 29.17 & 66.67 & 58.33 \\
\hline Niacin & 59.43 & 71.58 & 80.88 & 86.05 \\
\hline Ascorbic acid & 65.02 & 71.86 & 78.33 & 80.99 \\
\hline Sodium & 85.77 & 74.42 & 71.43 & 57.33 \\
\hline Potassium & 96.87 & 91.19 & 90.57 & 90.12 \\
\hline Calcium & 102.27 & 106.02 & 98.67 & 103.36 \\
\hline Magnesium & 105.21 & 101.79 & 103.16 & 103.99 \\
\hline Phosphorus & 94.70 & 92.70 & 85.96 & 82.51 \\
\hline Iron & 91.40 & 73.63 & 69.23 & 59.65 \\
\hline Zinc & 89.83 & 72.23 & 68.08 & 64.59 \\
\hline Manganese & 89.61 & 81.81 & 74.94 & 65.84 \\
\hline Copper & 82.64 & 63.36 & 54.27 & 46.83 \\
\hline
\end{tabular}

Sample 2 = Cooked undecanted water, Sample $3=$ Cooked and decanted water, Sample $4=$ Pressure-cooked undecanted water, Sample $5=$ Pressure cooked and decanted water 


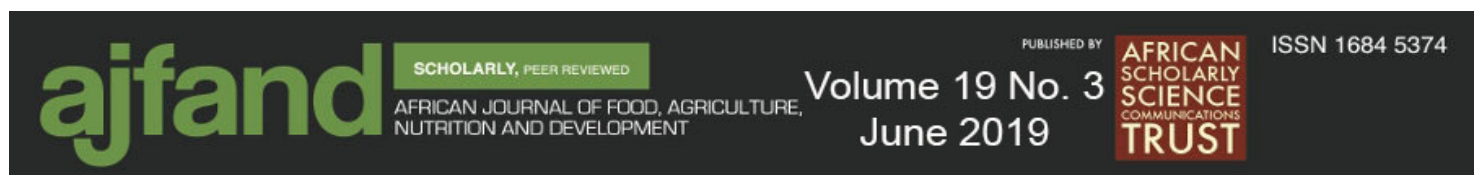

\section{REFERENCES}

1. Saxena KB, Kumar RV and CLL Gowda Vegetable pigeon pea - a review. International crops research institute for semi- arid tropics, Patanchenru, India 2010; 23(2): 91-98.

2. Adebowale KO and OS Lawal Comparative study of the functional properties of bambara groundnut (Voandzeia subterranean), jack bean (Cavanalia ensiformis). Food Chem., 2004;83:237-246.

3. Ghadge PN, Vairagar PR and K Prasad Some Physical Properties of Chick Pea Split (Cicer arietinum L.). Agricultural Engineering International: The CIGR Ejournal. 10 (FP 07 039), 2008.

4. Adeparusi EO Effect of processing on some minerals, anti-nutrients and nutritional composition of African yam bean. Journal of Sustainable Agriculture and Environment 2001; 3: 101-108.

5. Fasoyiro SB, Ajibaded SR, Omole AJ, Adeniyan ON and EO Farinde Proximate, mineral and anti-nutritional factors of some under-utilized grain legumes in South-West Nigeria. Nutr. Food Sci. 2006; 38:18-23.

6. Chikwendu NJ Chemical composition of four varieties of ground bean (kerstingiella geocarpa). J. Agric., Food, Environment and Extension 2007; 6 (2): 73-84.

7. Aiyeloja AA and OA Bello Ethnobotanical potentials of common herbs in Nigeria: A case study of Enugu state. Educational Research and Review 2006; 1: 16-22.

8. Odeny DA The potential of pigeon pea (Cajanus cajan L. Millsp.) in: Africa. Natural Resources Forum 2007; 31:297-305.

9. Philip TA An Agricultural Notebook, Mc-Graw Hill Publisher, London 2002; 88 (157): $44-46$.

10. Fasoriyo SB, Obatolu VA, Asaye OA, Adeojo EA and DO Ogunleti Chemical $\&$ Sensory qualities of pigeon pea (cajanus cajan) developed into a local spice "dawadawa". Nig. Food J 2009; 27:150-150.

11. Amaefule KU and NN Nwagbara The effect of processing on nutrient utilization of pigeon pea (Cajanus cajan) seed meal \& pigeon pea seed meal based diets by pullets Inj. J. poult. Sci. 2004; 3:543.

12. Fasoyiro SB, Akande SR, Arowora KA, Sodeko OO, Sulaiman PO, Olapade CO and Odiri CE Physico-chemical and sensory properties of pigeon pea (Cajanus cajan) flours, African Journal of Food Science 2010; 4(3): 120-126. 


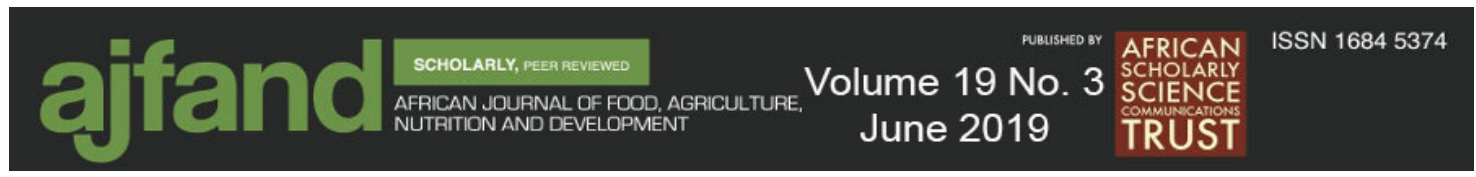

13. Fasoyiro SB, Ajibade SR, Saka JO, Ashaye OA, Obatolu VA, Farinde EO and OO Afolabi Physical characteristics and effect of processing methods on pigeon pea varieties (Cajanus cajan). J. Food Agric. Environ. 2005; 3:59-61.

14. Adepoju OT, Adekola YG, Mustapha SO and SI Ogunola Effect of processing methods on nutrient retention and contribution of local diets from cassava (Manihot spp) to nutrient intake of Nigerian consumers. African Journal of Food Agriculture, Nutrition and Development (AJFAND) 2010; 10(2): 2099 - 2111.

15. Khalil AW, Zeb A, Mahmood F, Tariq S, Khattak AB and HU Shah Comparison of sprout quality characteristics of desi and kabuli type chickpea cultivars (Cicer arietinum L.). LWT 2007; 40: 937-945.

16. AOAC. Official Methods of Analysis of the Association of Analytical Chemists $18^{\text {th }}$ edn, Washington, D C, U S A 2005.

17. Murphy EW, Criner PE and BC Gray Comparisons of methods for calculating retention in cooked foods. J. Agric. Food Chem. 1975; 23:1153-1157.

18. Amarteifio JO, Munthali DC, Karikari SK and TK Morake The composition of pigeon pea (Cajanus cajan (L.) Millsp.) grown in Botswana. Plant Foods for Human Nutrition, 2002; 57: 173-177.

19. Abdel RS, Mohammed E, Ali OA and R Haron The chemical composition of pigeon pea (cajanus cajana) seed and funvtional properties of protein isolate. Pakistan journal of nutrition, 2010; 9:1069-1073.

20. Rehman AR and IA Khalil Retention of selected nutrients in cooked kidney beans (Phaseolus vulgaris. L.). J. Agric. Food Chem. 1988; 32: 342-346.

21. Obioha FC A Guide to Poultry Production in the Tropics. Enugu, Nigeria, Acena Publishers (1992).

22. Aduku AO Tropical Feedstuff Analysis Table. Department of Animal Science, Faculty of Agriculture, Ahmadu Bello University, Samaru, Zaria, Nigeria (1993).

23. Amaefule KU and FC Obioha Performance and nutrient utilization of broiler starters feed diets containing raw, boiled or dehulled pigeon pea seeds (Cajanus cajan). Nigerian Journal of Animal Production, 2001; 28: 31-39.

24. Onu PN and SN Okongwu Performance characteristics and nutrient utilization of starter broilers fed raw and processed pigeon pea (Cajanus cajan) seed meal. International Journal of Poultry Science, 2006; 5(7): 693-697.

25. Bamigboye AY and OT Adepoju Effects of processing methods on nutritive values of Ekuru from two cultivars of beans (Vigna unguiculata and Vigna angustifoliata). Afri. J. Biotechnology 2015; 14 (21): 1790 - 1795. 
26. Adeparusi EO Evaluation of the nutritive potential of cooked pigeon pea (Cajanus cajan) meal as a plant protein source for Clarias gariepinus fingerlings. Journal Agricultural Technology, 1994; 2(1): 48-57.

27. Arawande JO and FB Borokini Comparative study on chemical composition and functional properties of three Nigerian legumes (jack beans, pigeon pea and cowpea). J. Emerging Trends in Engineering and Applied Science (JESTAS), 2010; 1 (1): 89-95.

28. Roth AR and CE Townsend Nutrition and diet therapy 8th edn. Delmar Learning, Thomson Learning Inc. Canada. 2003, 148 - 160.

29. Meiner CR, Derise NL, Lau HC, Crews MG, Ritchey and EW Murphy The content of nine mineral elements in raw and cooked mature dry legumes. J. Agric. Food Chem. 1976; 24:1126-1130.

30. Nwokolo E Nutritional evaluation of pigeon pea meal. Plt. Food. HumanNutr.1987;37:283-290.

31. Faris DG, Saxena KB, Mazumdar S and U Singh Vegetable pigeon pea: a promising crop in India. ICRISAT, Patancheru, A.P. 502 324, India: International Crops Research Institute for the Semi - Arid Tropics (1987). 